\title{
Dynamic Aspects of Contact Angle Measurements on Adsorbed Protein Layers
}

\author{
AT VAN DER SCHEER AND CEES A. SMOLDERS \\ Department of Chemical Technology, Twente University of Technology, \\ P.O. Box 217, Enschede, The Netherlands
}

Received September 7, 1976; accepted April 26, 1977

\begin{abstract}
Contact angle measurements using drops of paraffin oil have been performed on polystyrene (PS) substrates, coated with human serum albumin (HSA) or human fibrinogen (HFb), immersed in buffer solution. The contact angle appeared to be time dependent. The final value for HSAcoated substrates was $50^{\circ} \pm 5^{\circ}$ and for $\mathrm{HFb}$-coated substrates $130^{\circ} \pm 10^{\circ}$ (measured through the oil phase). From measurements of the interfacial tension at oil/buffer interfaces on passing HSA-coated substrates and from measurements using radio-labeled HSA in such experiments, it may be concluded that an adsorbed layer of HSA on PS can turnover from the PS substrate to the oil/buffer interface. The difference in behavior between PS substrates coated with HSA and PS surfaces coated with $\mathrm{HFb}$ is attributed to association of the $\mathrm{HFb}$ molecules upon adsorption at the PS/buffer interface, whereas the stronger intramolecular forces in HSA do prevent this behavior.
\end{abstract}

\section{INTRODUCTION}

When blood is contacted with the surface of an artificial material, adsorption of proteins will occur instantaneously. At the same time blood coagulation will be initiated by a contact activation mechanism. Andrade $(1,2)$ postulates that this activation is a function of the interfacial free energy between blood and the exposed surface. This implies that it is important to investigate how the nature of the exposed surface and the balance of intermolecular forces will be altered upon adsorption of protein molecules. Once the protein is adsorbed, the other blood components might only interact with the adsorbed protein layer, masking the underlaying material.

Vroman (3) studied the effect of the nature of the exposed surface on the adsorbed protein layer. He used a roughly estimated contact angle value of water on different surfaces, coated with human fibrinogen, as an indication for the state of the protein layer. The protein-coated surfaces were dried before judging their wettability.
McMillin and Walton (4) studied the influence of drying on the conformation of the adsorbed protein. It appears that an adsorbed layer of a certain protein (Hageman factor) shows entirely different ORD (optical rotation dispersion) spectra for coated substrates which were dried and for those which were nondried. These observations are not surprising, considering the important role of water in the tertiary structure of proteins (Lumrey (5), Bachmann (6)), and of possible irreversible changes in conformation upon drying.

In this study, contact angle measurements have been performed with paraffin oil drops brought in contact with proteincoated substrates immersed in buffer solutions. The buffer solution, which contains no protein, has been used to replace the original protein solution from which adsorption took place. In this way, the possible effect of drying of the coated substrates was prevented. The polar interactions between adsorbed protein and water will be investigated, as well as dynamic aspects of 
the wetting behavior of the oil drops on the immersed protein-coated substrates.

As substrate material polystyrene has been chosen, which is a very apolar material. The proteins under investigation are human fibrinogen and human serum albumin.

\section{EXPERIMENTAL}

\section{Materials}

Human serum albumin (HSA), crystallized, was obtained from Pierce Chemicals. Prod. No. 30430.

$\left[{ }^{125} I\right] H S A$ (batches with varying concentrations $\sim 7 \mathrm{~kg} \mathrm{~m}^{-3}$ ) was obiained from I. R. E. Fleurus, Belgium, No. Sari 125-B. Human fibrinogen (HFb), >90\% clottable, was obtained from AB Kabi, Stockholm.

Polystyrene (PS) was obtained from Pressure Chemical Company, Pittsburgh, Mellon Institute, Special Polystyrene standard. $M_{\mathrm{w}}=670,000 ; M_{\mathrm{w}} / M_{\mathrm{n}}=1.15$, lot No. 13a.

Paraffin oil was obtained from Baker Chemicals, Deventer, Holland. Before use, it was twice purified by percolating over an $\mathrm{Al}_{2} \mathrm{O}_{3}$ column.

Buffer solution was prepared by adding an aqueous solution of $0.01 \mathrm{M} \mathrm{KH}_{2} \mathrm{PO}_{4}$ and $0.15 \mathrm{M} \mathrm{NaCl}$ to an aqueous solution of $0.01 M \mathrm{NaOH}$ and $0.15 M \mathrm{NaCl}$ until a $\mathrm{pH}$ of 7.4 was reached. All protein solutions were stored at a temperature of $277^{\circ} \mathrm{K}$, under sterile conditions, and they were used within 1 week after preparation.

All chemicals used were analytical grade.

METHODS

\section{Contact Angle Measurements}

Polystyrene (PS) substrates were obtained by dipping glass surfaces in a solution of PS in toluene (7\%) and drying them afterward. The dipping procedure was repeated three times. After the third time, the substrate was dried during 1 day at room temperature. Drying during 1 week at a temperature above the glass transition of PS did not give different contact angle results. Subsequently, the substrates were conditioned in a buffer solution for 1 day. Then the substrate was placed in a fresh buffer solution $(\mathrm{pH}=7.4)$ after which a concentrated protein solution was added until the desired protein concentration in the range from 0.002 to $0.5 \mathrm{~kg} \mathrm{~m}^{-3}$ was reached. After $3 \mathrm{hr}$ the protein solution was washed away by buffer solution containing no protein at all. The replacement of protein solution is a necessary step in the procedure, first to be sure that the oilwater interfacial tension during contact angle measurements did not change due to adsorption of protein from the solution, and second to prevent contact between the substrate and the protein solution/air interface after the adsorption step. If this contact occurs, the adsorbed and probably denaturated protein layer at the air/solution interface may be deposited on the substrate (Ghosh and Bull (7)) as a kind of Blodgett (8) layer.

Subsequently, the substrate was taken out, put directly into a cell containing buffer solution, and placed on a platform in the contact angle measurements setup. Using a glass capillary, a small drop of paraffin oil $\left(\sim 10^{-11} \mathrm{~m}^{3}\right)$ was brought under the substrate. The contact angle $\theta$ of this drop with the substrate was determined from the dimensions of the drop (Bargeman (9)), see Fig. 1. A necessary condition for this method is that the shape of the drop is not influenced by gravity (small drops should be used).

\section{RESULTS}

The contact angle $\theta$ of paraffin oil measured through the oil phase upon clean PS substrates immersed in buffer solution containing no protein appeared to be

$$
\theta=30^{\circ} \pm 3^{\circ} \text {. }
$$

Measurements of the contact angle of paraf- 


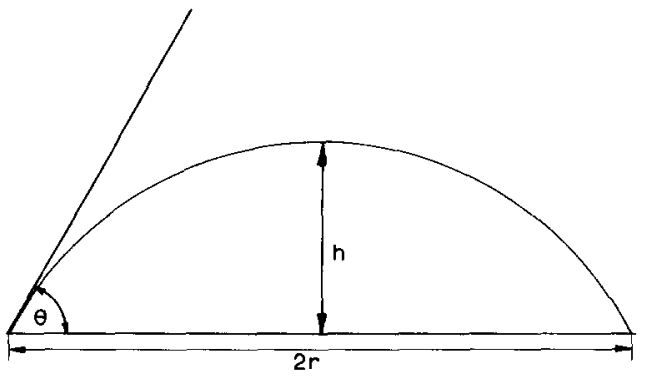

FIG. 1. $\sin \theta=2 h r /\left(h^{2}+r^{2}\right)$.

fin oil with PS substrates immersed in a buffer solution deliberately containing 0.5 $\mathrm{kg} \mathrm{m}^{-3}$ protein yielded an angle of contact being

$$
\theta=180^{\circ} .
$$

In this system no wetting of the substrate by the oil drop was observed at all, not even after prolonged waiting ( $>1$ day).

Substrates were prepared carrying protein layers adsorbed from different protein solutions as described before. Buffer solutions containing $0.5,0.05,0.01$, and 0.002 $\mathrm{kg} \mathrm{m} \mathrm{m}^{-3}$ HSA and, in a second series, buffer solutions containing $0.5,0.05$, and $0.002 \mathrm{~kg} \mathrm{~m}^{-3} \mathrm{HFb}$ were used as adsorption liquids. After replacement of the protein solutions, contact angles were measured as a function of time of contact of the oil drop.
Results obtained with HSA-coated substrates are given in Fig. 2. Immediately after depositing the paraffin oil drop onto the surface, the contact angle is $180^{\circ}$. This situation could be maintained for longer periods if the substrate was kept in vibration by tapping against it. Without this mechanical influence the angle of contact decreased as a function of time. The rate of decrease and the final value of the contact angle seemed to be quite independent of the protein concentration in the solution from which the protein layer had been adsorbed. After $2 \times 10^{3} \mathrm{sec}$ of contact, $\theta$ was about $65^{\circ}$ and after $10^{4} \mathrm{sec}$ the ultimate value of $\theta=50^{\circ} \pm 5^{\circ}$ was practically reached.

Results obtained with HFb-coated substrates are given in Fig. 3. The contact angle measured on these substrates decreased much less than was observed for the HSA-coated substrates. The initial value was also $180^{\circ}$, which situation also could be prolonged by tapping, but the final value of $\theta$ was $120^{\circ}$ to $140^{\circ}$. Again this value was shown to be independent of the protein concentration in the solution from which the protein had been adsorbed.

In order to investigate the influence of drying of the adsorbed protein layer on the wetting behavior of paraffin oil, some protein-coated surfaces were dried for 1 day at

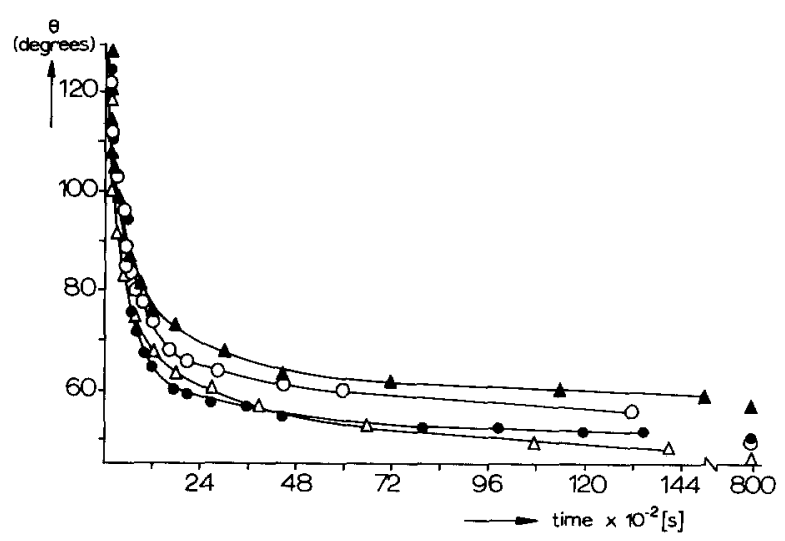

FIG. 2. The time dependence of the contact angle $\theta$ on HSA-coated PS substrates in buffered salt solutions $\left(\mathrm{pH}=7.4, T=293^{\circ} \mathrm{K}\right.$ ). The protein was adsorbed from buffered solutions containing 0.5 $(\odot), 0.05(O), 0.01(\Delta)$, and $0.002 \mathrm{~kg} \mathrm{~m}^{-3}(\triangle)$ HSA, respectively. 


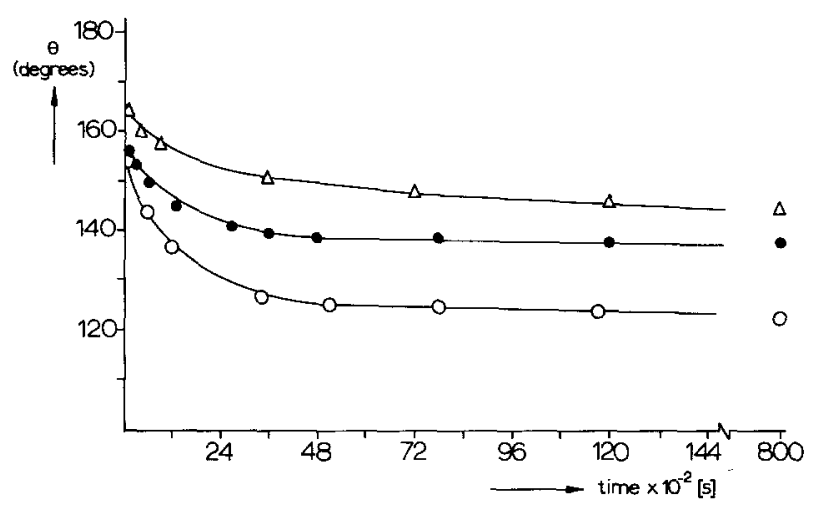

FIG. 3. The time dependence of the contact angle $\theta$ on HFb-coated PS substrates in buffered salt solution $\left(\mathrm{pH}=7.4, \mathrm{~T}=293^{\circ} \mathrm{K}\right.$ ). The protein was adsorbed from buffered solutions containing 0.5 $(\odot), 0.05(\mathrm{O})$, and $0.002 \mathrm{~kg} \mathrm{~m}^{-3}(\triangle) \mathrm{HFB}$, respectively.

room temperature. Contact angle measurements on these substrates were performed as soon as possible after their immersion in buffer solution. The results of this type of measurement, carried out with substrates obtained originally by adsorption from a buffer solution containing $0.5 \mathrm{~kg} \mathrm{~m}^{-3} \mathrm{HSA}$, are given in Fig. 4 and from buffer solutions containing $0.5,0.05$, and $0.002 \mathrm{~kg} \mathrm{~m}^{-3}$ $\mathrm{HFb}$, respectively, in Fig. 5.

In contradistinction to the situation for nondried protein layers, the initial contact angles are smaller than $180^{\circ}$ here. The contact angle on the intermediately dried HSA surface still shows a time dependence (Fig. 4), whereas the fibrinogen substrates obtained from 0.5 and $0.05 \mathrm{~kg} \mathrm{~m}^{-3}$ solutions immediately show constant contact angles. The $\mathrm{HFb}$-coated substrates ob- tained from $0.002 \mathrm{~kg} \mathrm{~m}^{-3}$ solutions show a decrease of $\theta$ as a function of time (Fig. 5).

\section{DISCUSSION}

For a three-phase system, paraffin oil/ water/solid, the relation between the contact angle of an oil drop on the solid surface which is immersed in the aqueous phase is given by the Young-equation:

$$
\gamma_{\mathrm{o}, \mathrm{w}} \cos \theta=\gamma_{\mathrm{s}, \mathrm{w}}-\gamma_{\mathrm{s}, \mathrm{o}},
$$

where $\gamma$ is the interfacial tension [ $\mathrm{m} N \mathrm{~m}^{-1}$ ], $\theta$ is the contact angle measured through the oil phase, and $\mathrm{s}, \mathrm{w}$, and $\mathrm{o}$ indicate the solid, water, and oil phase, respectively.

The interfacial tension between two mutually nondissolving phases 1 and 2 equals

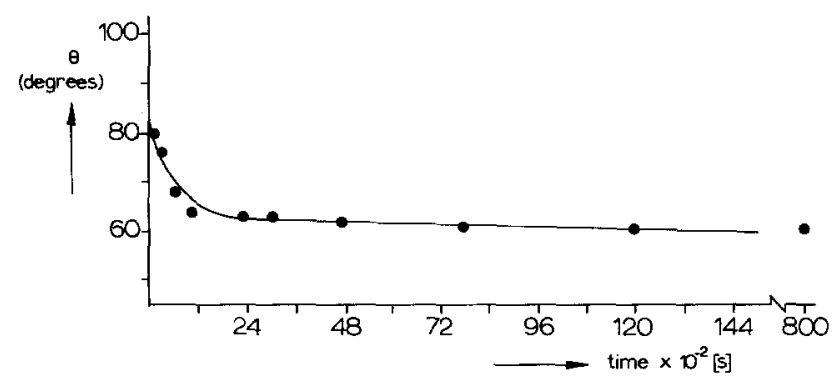

FIG. 4. The time dependence of the contact angle $\theta$ on intermediately dried HSA-coated PS substrates in buffered salt solution $\left(\mathrm{pH}=7.4, \mathrm{~T}=293^{\circ} \mathrm{K}\right)$. The protein was adsorbed from buffered solutions containing $0.5 \mathrm{~kg} \mathrm{~m}^{-3} \mathrm{HSA}$. 


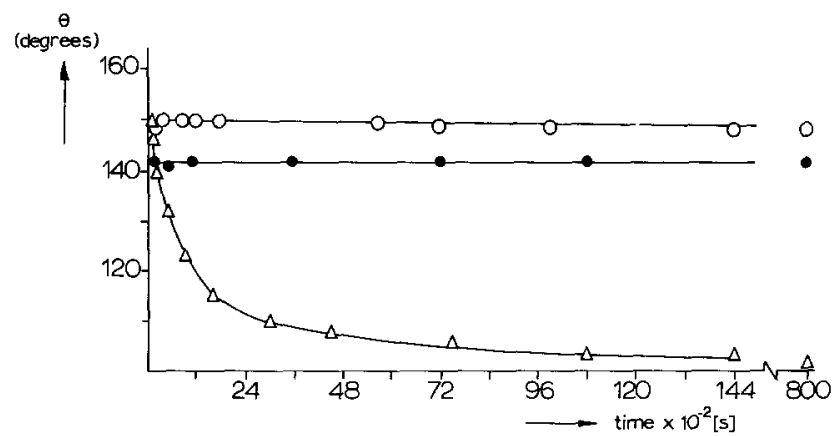

FIG. 5. The time dependence of the contact angle $\theta$ on intermediately dried HFb-coated PS substrates in buffered salt solution $\left(\mathrm{pH}=7.4, \mathrm{~T}=293^{\circ} \mathrm{K}\right)$. The protein was adsorbed from buffered solutions containing $0.5(\bigcirc), 0.05(\bigcirc)$, and $0.002 \mathrm{~kg} \mathrm{~m}^{-3}(\triangle) \mathrm{HFb}$, respectively.

the sum of the surface tensions of the phases in vacuum minus twice the free energy of interaction $\left(\gamma_{1,2}^{\prime}\right)$ between the two phases.

$$
\gamma_{1,2}=\gamma_{1}+\gamma_{2}-2 \gamma_{1,2}^{\prime} \text {. }
$$

This free energy of interaction can be subdivided into two parts: (1) a contribution due to dispersive interaction $\left(\gamma_{1,2}^{\prime}\right)$ and (2) a contribution due to nondispersive interactions $\left(1 / 2 I_{1,2}\right)$ or

$$
\gamma_{1,2}^{\prime}=\gamma_{1,2}^{d}+1 / 2 I_{1,2} .
$$

Fowkes (10) showed semiempirically that $\gamma_{1,2}^{\prime}{ }^{d}=\left(\gamma_{1}{ }^{d} \gamma_{2}{ }^{d}\right)^{1 / 2}$, where $\gamma_{1}{ }^{d}$ and $\gamma_{2}{ }^{d}$ are the dispersive contributions to the surface tensions of phase 1 and phase 2 , respectively. Substitution into Eq. [2] gives

$$
\gamma_{1,2}=\gamma_{1}+\gamma_{2}-2\left(\gamma_{1}{ }^{\mathrm{d}} \gamma_{2}{ }^{\mathrm{d}}\right)^{1 / 2}-I_{1,2} \text {. }
$$

It is assumed that the surface tension of paraffin oil results from van der Waals forces only, so $\gamma_{0}=\gamma_{0}{ }^{\mathrm{d}}$. In this study, contact angle measurements have been performed with paraffin oil drops on clean PS substrates immersed in buffer solution and on protein-coated PS substrates immersed in buffer solution; these surfaces will be indicated, respectively, by the indices s and $s(p)$. Young's equation for system $a$ (paraffin oil/buffer/PS) is

$$
\gamma_{\mathrm{o}, \mathrm{w}} \cos \theta_{a}=\gamma_{\mathrm{s}, \mathrm{w}}-\gamma_{\mathrm{s}, 0},
$$

and for system $b$ (paraffin oil/buffer/protein-coated PS)

$$
\gamma_{o, w} \cos \theta_{b}=\gamma_{\mathrm{s}(\mathrm{p})_{\mathrm{w}}}-\gamma_{\mathrm{s}(\mathrm{p})_{0}} .
$$

Using [4], [5], and [6],

$$
\begin{aligned}
\gamma_{0, \mathrm{w}} & \left(\cos \theta_{b}-\cos \theta_{a}\right) \\
= & \gamma_{\mathrm{s}(\mathrm{p})}+\gamma_{\mathrm{w}}-2\left(\gamma_{\mathrm{s}(\mathrm{p})}{ }^{\mathrm{d}} \gamma_{\mathrm{w}}{ }^{\mathrm{d}}\right)^{1 / 2}-I_{s(\mathrm{p}) \mathrm{w}}-\gamma_{\mathrm{s}} \\
& -\gamma_{\mathrm{w}}+2\left({\gamma_{\mathrm{s}}}^{\mathrm{d}}{\gamma_{\mathrm{w}}}^{\mathrm{d}}\right)^{1 / 2}-\gamma_{\mathrm{s}(\mathrm{p})}-\gamma_{\mathrm{o}} \\
& +2\left(\gamma_{\mathrm{s}(\mathrm{p})}{ }^{\mathrm{d}} \gamma_{0}\right)^{1 / 2}+\gamma_{\mathrm{s}}+\gamma_{\mathrm{o}}-2\left(\gamma_{\mathrm{s}}^{\mathrm{d}} \gamma_{0}\right)^{1 / 2}
\end{aligned}
$$

or

$$
\begin{aligned}
& \gamma_{0, \mathrm{w}}\left(\cos \theta_{b}-\cos \theta_{a}\right) \\
& \begin{aligned}
=2\left(\gamma_{\mathrm{s}(\mathrm{p})}{ }^{\mathrm{d}}\right)^{1 / 2}-\left(\gamma_{\mathrm{s}}{ }^{\mathrm{d}}\right)^{1 / 2}\left(\gamma_{\mathrm{o}}{ }^{1 / 2}\right. & \left.-\left({\gamma_{\mathrm{W}}}^{\mathrm{d}}\right)^{1 / 2}\right) \\
& -I_{\mathrm{s}(\mathrm{p}) \mathrm{w}} .
\end{aligned}
\end{aligned}
$$

Equation [7] has been obtained on the basis that the clean PS substrate has no nondispersive interactions with the aqueous phase (9) and also that the clean and the protein-covered PS surface shows no polar interaction with the oil phase. Introduction of $\gamma_{\mathrm{w}}{ }^{\mathrm{d}}=21.8 \mathrm{mN} \mathrm{m}^{-1}$ and $\gamma_{\mathrm{o}}=32 \mathrm{mN}$ $\mathrm{m}^{-1}$ simplifies the first term on the right, yielding

$$
\begin{aligned}
& \gamma_{o, w}\left(\cos \theta_{b}-\cos \theta_{a}\right) \\
& \left.=2\left(\gamma_{s(p)}{ }^{d}\right)^{1 / 2}-\left(\gamma_{s}^{d}\right)^{1 / 2}\right)-I_{s(p) w} .
\end{aligned}
$$

Values for $\gamma_{\mathrm{s}(\mathrm{p})}{ }^{\mathrm{d}}$ are not available, but considering that the value of $\gamma_{\mathrm{s}(p)}{ }^{\mathrm{d}}$ might be somewhere between 46 and $21.8 \mathrm{mN} \mathrm{m}^{-1}$ (the values of $\gamma^{d}$ for nylon 6-6 (11) and water, respectively), it can be stated that

$$
4.5<\left(\gamma_{\mathrm{s}(\mathrm{p})}^{\mathrm{d}}\right)^{1 / 2}<7 .
$$


Introduction of this value and the $\gamma_{s}{ }^{d}$ value for polystyrene (12) $\left(44 \mathrm{mN} \mathrm{m}^{-1}\right)$ in Eq. [8] yields

$$
\begin{aligned}
& \gamma_{0, \mathrm{w}}\left(\cos \theta_{a}-\cos \theta_{b}\right) \\
& =I_{\mathrm{s}(\mathrm{p}) \mathrm{w}} \pm 5 \mathrm{mN} \mathrm{m}^{-1} .
\end{aligned}
$$

From the final contact angle $\theta_{b}=50^{\circ}$ $\pm 5^{\circ}$ (Fig. 2) measured on HSA-coated substrates and $\theta_{a}=30^{\circ} \pm 3^{\circ}$ measured on clean PS substrates it may be concluded that

$$
0<I_{\mathrm{s}(\mathrm{p}) \mathrm{W}}<20 \mathrm{mN} \mathrm{m}^{-1}
$$

for HSA-coated surfaces.

From the final contact angle $\theta_{b}=120^{\circ}-$ $140^{\circ}$ (Fig. 3) measured on $\mathrm{HFb}$-coated substrates and $\theta_{a}=30^{\circ} \pm 3^{\circ}$ it may be concluded that

$$
65<I_{\mathrm{s}(\mathrm{p}) \mathrm{w}}<85 \mathrm{mN} \mathrm{m}^{-1}
$$

for $\mathrm{HFb}$-coated surfaces.

The difference between the calculated values for the nondispersive interactions of $\mathrm{HSA}$ and $\mathrm{HFb}$ with water is much greater than can be expected from the differences in the chemical composition of these molecules. It is known that both proteins are well soluble in water. When, for instance, $\mathrm{HFb}$ is dissolved in an aqueous solution, it contains water up to four times its own weight (6). From these data it is to be expected that there is a strong interaction between these proteins and water. Since the $I$-term acting across a hypothetical water/ water interface can be calculated to be $\sim 100 \mathrm{mN} \mathrm{m}^{-1}\left(I_{\mathrm{ww}}=\gamma_{\mathrm{w}}+\gamma_{\mathrm{w}}-2\left(\gamma_{\mathrm{w}}{ }^{\mathrm{d}} \gamma_{\mathrm{w}}{ }^{\mathrm{d}}\right)^{1 / 2}\right.$ $\approx 100 \mathrm{mN} \mathrm{m}^{-1}$ ), it might be concluded that the value of $I_{s(p) w}$ must be of the same order. This means that the $I_{\mathrm{s}(\mathrm{p})_{\mathrm{w}}}$ found for $\mathrm{HFb}$ /water has an acceptable value $\left(65-85 \mathrm{mN} \mathrm{m}^{-1}\right)$. It also means that in the case of HSA-coated substrates something has happened which causes an unlikely low value of $I_{\mathrm{s}(\mathrm{p}) \mathrm{w}}$ to be calculated. A different behavior of HSA-coated substrates compared to $\mathrm{HFb}$-coated substrates has been observed already with the dried substrates (Figs. 4 and 5). Figure 4 shows that the contact angle on the intermediately dried HSA substrates still shows a time dependence, whereas Fig. 5 shows no time dependence for the contact angles measured on intermediately dried $\mathbf{H F b}$ substrates.

Three possible explanations can be given for the difference in the contact angle vs time behavior of the adsorbed protein layers under investigation:

(1) The conformation of the adsorbed protein layer changes drastically under the influence of the oil drop.

(2) The adsorbed protein layer dissolves in the buffer solution.

(3) The adsorbed protein layer is "stripped" off from the PS surface by the paraffin oil drop. This will result in the presence of protein at the oil/water interface.

The second possibility can be ruled out since the behavior of an oil drop on a protein-coated substrate did not change when this protein-coated substrate was incubated for several hours in a proteinfree buffer solution. So we only have to consider the first and the last mentioned possibility. Reconformation of protein molecules situated between PS and the oil drop cannot be ruled out, but it does not seem to be a very obvious process.

When the last mentioned possibility occurs, the value of $\gamma_{0, w}$ will decrease. It is not possible to directly measure this decrease of $\gamma_{0, w}$ at the advancing interface of a very small drop of paraffin oil. However, the situation of a slowly advancing contact angle can be simulated by pulling protein-coated PS platelets very slowly through an oil/buffer solution interface. When "stripping" occurs, the interfacial tension $\left(\gamma_{0, w}\right)$ will decrease, resulting from the presence of "stripped" protein at the interface. This experiment has been performed as follows.

Glass plates $(0.024 \times 0.040 \mathrm{~m})$ were coated with polystyrene and HSA was adsorbed from a buffered solution containing $0.5 \mathrm{~kg} \mathrm{~m}^{-3} \mathrm{HSA}$. After the replacement of the protein solution by buffer solution 
without protein, the platelets were taken out all wet and placed in a beaker containing buffer solution. Then a layer of paraffin oil was carefully brought on top of the buffer solution and the interfacial tension $\gamma_{0, w}$ was measured using the Wilhelmyplate method (check on wetting angle). Subsequently, the protein-coated platelets are pulled very slowly $\left(1-2 \mu \mathrm{m} \mathrm{sec}{ }^{-1}\right)$ through the oil/buffer interface, after which the interfacial tension was measured again. The interfacial tension had decreased from 50 to $43-45 \mathrm{mN} \mathrm{m}^{-1}$.

From these experiments it is concluded that at least a part of the time dependence of the contact angle measurements on HSA substrates, dried and nondried, results from the "stripping" of the adsorbed HSA layer by the oil drop.

In order to verify this feature in still a different way, experiments with radio-labeled HSA have been performed. For these experiments HSA, labeled with ${ }^{125} \mathrm{I}\left(\left[{ }^{125} \mathrm{I}\right]-\right.$ HSA), was used.

Polystyrene substrates were coated with a protein layer by adsorption from a buffer solution containing $\left[{ }^{125} \mathrm{I}\right] \mathrm{HSA}$ and HSA with a total protein concentration of $0.5 \mathrm{~kg} \mathrm{~m}^{-3}$. The adsorption procedure has been described elsewhere (13). The HSA-coated substrates were placed in a beaker containing buffer solution only. Some of the plates were connected to a mechanism which could pull them upwards with a rate of 1 or $2 \mu \mathrm{m} \mathrm{sec}{ }^{-1}$, and a layer of paraffin oil was carefully brought on top of the solution; the others were placed in another beaker with buffer solution. After $20 \mathrm{hr}$ the substrates were taken out: the first series of substrates had passed the oil/buffer interface by means of the mentioned mechanism and the other series of substrates were taken out directly from the buffer solution. The surface concentration of HSA on the substrates was measured with a scintillation counter (Baird atomic spectrometer Model 530). The results are given in Table I.

By these experiments it has been con- firmed that an oil drop can "strip" an adsorbed layer of HSA from a polystyrene surface, with an increased effectivity of this "stripping" upon a decrease in the transport rate of the boundary line.

A similar effect has been found by Bikerman (14) for deposited multilayers of barium stearate; the phenomenon was called boundary corrosion. The adsorption of barium stearate, however, is reversible, whereas for an explanation of this stripping effect it is necessary to realize that the adsorption of macromolecules like HSA and $\mathrm{HFb}$ is generally assumed to be irreversible and that each adsorbed protein molecule will be adsorbed at the apolar substrate by a number of apolar segments. The assumed irreversibility does not necessarily mean that each binding site shows irreversibility in adsorption. There is, however, statistically an extremely small possibility that desorption occurs at all the contact places at the same time.

The observed "strip effect" proves that each of the trains of segments with which the HSA molecules are adsorbed onto the surface is bound in a reversible way. This can be visualized schematically as follows (Fig. 6).

A drop of paraffin oil has been brought in contact with a protein-coated surface immersed in buffer solution. Initially the observed contact angle (measured through the oil phase) will remain $180^{\circ}$ (Fig. 6a), possibly resulting from a retarded reori-

TABLE I

The Amounts of Protein Present on PS Substrates which Have Been or Have Not Been Drawn through an Oil/Buffer Interface

\begin{tabular}{ccc}
\hline $\begin{array}{c}\text { Surface concentration } \\
\text { of HSA on PS } \\
\text { substrate without } \\
\text { passing the oil/ } \\
\text { buffer interface } \\
\left(\times 10^{5}\right) \\
\left(\mathrm{kg} \mathrm{m}^{-2}\right)\end{array}$ & $\begin{array}{c}\text { Surface concentration } \\
\text { of HSA on PS } \\
\text { substrate after } \\
\text { passing the oil/ } \\
\text { buffer interface } \\
\left(\times \mathrm{m} \mathrm{sec}^{-1}\right)\end{array}$ & $\begin{array}{c}\left(\times 10^{6}\right) \\
\left(\mathrm{kg} \mathrm{m}^{-2}\right)\end{array}$ \\
\hline 1 & 1.6 & 0.4 \\
2 & 1.6 & 0.8 \\
\hline
\end{tabular}




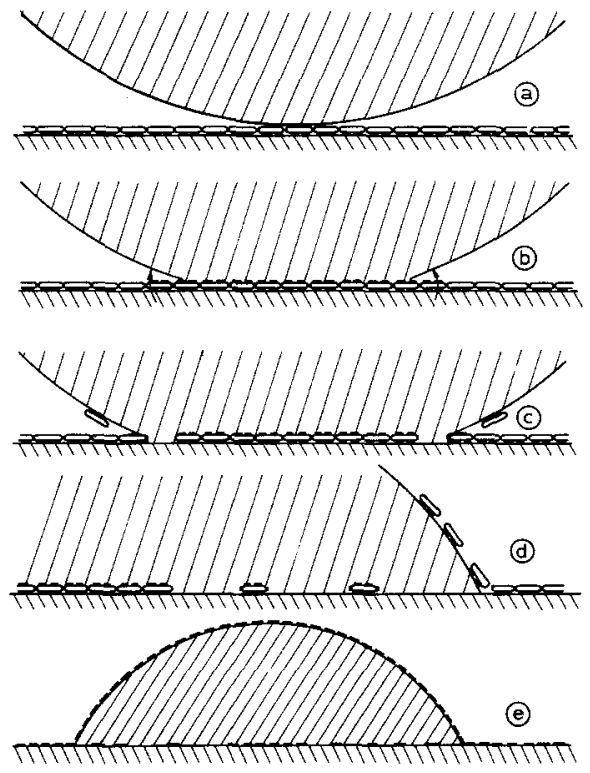

Frg. 6. Schematical wetting process of an oil drop onto a protein coated PS substrate. (a) initial situation; (b) finite contact angle on the protein layer and the first turnover of the protein molecules; (c) wetting of the PS substrate by the paraffin oil; (d) "stripping" of the protein molecules; (e) final situation.

entation of hydrophilic segments of the adsorbed protein molecules in the thin water film next to the protein layer. This nonwetting was shown to be a dynamic effect; it could be prolonged when the substrate was kept in vibration causing displacement of the drop. Hence the adhesional forces are very weak in the beginning, and there is no spontaneous tendency for the water layer in contact with the protein layer to break away. The phenomenon that on intermediately dried surfaces the initial contact angle was smaller than $180^{\circ}$ might indicate that, upon drying the adsorbed protein layer, reconformation occurs from a hydrophillic outer layer to a (at least partially) hydrophobic outer layer. When the water layer breaks, the oil-protein contact will be realized and a finite contact angle (Fig. 6b) will be established. At the three phase boundary the protein may adsorb at the paraffin oil/water interface also. Then the protein molecules can be peeled off from the PS (Fig. 6b), because the inter- action of the protein molecules with the liquid oil can be stronger than with the solid PS, resulting from the flexibility of liquid-liquid interfaces.

Now the oil phase may be able to reach the underlying apolar substrate at some places (Fig. 6c). The protein molecules are supposed to be long ellipsoids connected to the surface by a number of apolar segments (the dots in Fig. 6a-d). When such a segment next to the oil phase contact line desorbs, the oil will proceed spreading on the PS and the train will readsorb onto an apolar substrate, now the paraffin oil (Fig. 6d). In this way the protein molecules might slide over from the PS/ buffer interface to the paraffin oil/buffer interface (Fig. 6e), and the contact angle will show a time-dependent decrease.

Obviously the "strip effect"' takes place on albumin-coated substrates only and not on the fibrinogen-coated substrates. If the proposed mechanism of "stripping" is right then this difference cannot result from the higher molecular weight. It may result from the fact that fibrinogen molecules denaturate much easier than albumin molecules do. Hence the adsorbed fibrinogen molecules may show association at the surface, resulting in an extended, associated fibrinogen layer which cannot be "stripped" from the surface.

Morrisey and Stromberg (15) found that upon adsorption the infrared-bound fraction of fibrinogen increased, whereas this did not happen for albumin. They concluded that the internal binding of albumin is sufficient to prevent changes in the structure while adsorbed, even at low surface concentration. The increase of the bound fraction of fibrinogen upon adsorption may result from interfacial aggregation, which is in line with our measurements.

The time dependence of the contact angle on the intermediately dried $\mathrm{HFb}$ substrate, adsorbed from a $0.002 \mathrm{~kg} \mathrm{~m}^{-3} \mathrm{HFb}$ solution (Fig. 5), may be the result of an incomplete coverage of the surface so that complete association cannot occur. The absolutely nonwetting behavior of an oil drop 
on a PS substrate immersed in a protein solution $\left(0.5 \mathrm{~kg} \mathrm{~m}^{-3}\right)$ can be explained by entropic repulsion, caused by the adsorbed protein layers at the PS/solution and the paraffin oil/solution interfaces, or the lowering of the $\gamma_{0, w}$ by protein adsorption. This can be shown by the following calculations on, for instance, fibrinogen-coated substrates. From the experiments without protein in the buffer solution, we know that the final contact angle is about $130^{\circ}$. Further it is known that $\gamma_{0, \mathrm{w}}=50 \mathrm{mN} \mathrm{m}^{-1}$. So Eq. [6] becomes

$$
-32=\gamma_{\mathrm{s}(\mathrm{p}) \mathrm{w}}-\gamma_{\mathrm{s}(\mathbf{p}) \mathrm{o}}
$$

The values of $\gamma_{s(p) w}$ and $\gamma_{s(p) o}$ will not change upon addition of protein to the buffer solution. The value of $\gamma_{0, w}$, however, will decrease from 50 to $22 \mathrm{mN} \mathrm{m}^{-1}$ (pH $=7.4[\mathrm{NaCl}], 0.15 \mathrm{kmole} \mathrm{m}^{-3}, 25^{\circ} \mathrm{C}$, Wilhelmy-plate method). This means that when a finite contact angle would occur:

$$
22 \cdot \cos \theta=-32 \text {. }
$$

Because $\cos \theta$ never is smaller than -1 , the conclusion must be that no wetting occurs at all and $\theta=180^{\circ}$.

\section{CONCLUSIONS}

From contact angle measurements on polystyrene (PS) substrates coated with human fibrinogen ( $\mathrm{HFb}$ ), immersed in buffer solution, information can be obtained about the nondispersive (polar) interaction of a protein layer with water $\left(65-85 \mathrm{mN} \mathrm{m}^{-1}\right)$.

The time dependence of the contact angle of a drop of paraffin oil on a human serum albumin (HSA)-coated PS substrate immersed in buffer solution appeared to show two subsequent features.

(1) The disruption of a hydrated water layer on the protein layer (which is stable under dynamical conditions);

(2) the turnover of part of the adsorbed protein molecules, from the $\mathrm{PS} /$ buffer interface to the oil/buffer interface.

From this last feature, it may be concluded that the binding sites between the protein molecules and the substrate are reversible.
The influence of intermediate drying of the protein-coated substrates on the final contact angle appeared to be negligible, whereas the initial contact angle was influenced strongly; this suggests that the difference results from an incomplete hydration of the dried protein layer.

From the inability of adsorbed human fibrinogen to turn over from a PS substrate immersed in buffer to an oil drop, it may be concluded that the adsorbed fibrinogen molecules show interfacial association.

\section{ACKNOWLEDGMENTS}

The authors would like to thank Marcel A. Tanke Btw for most of the experimental work and Dr. Derk Bargeman's very valuable discussions.

\section{REFERENCES}

1. Andrade, J. D., Med. Instrumentation 7, 2 (1973).

2. Andrade, J. D., Lee, H. B., John, M. S., Kim, S. W., and Hibbs, J. B., Trans. Amer. Soc. Artif. Intern. Organs 19, 1 (1973).

3. Vroman, L., in "Blood clotting enzymology," (W. H. Seegers, Ed.), Capital 6, p. 283. Academic Press, New York/London, 1967.

4. McMillin, C. R., and Walton, A. G., J. Colloid Interface Sci. 48, 345 (1974).

5. Lumrey, R., Ann. N.Y. Acad. Sci., 227, 471485 (1974).

6. Bachmann, L., Schmitt-Fumian, W. W., Hammel, R., and Lederer, K., Makromol. Chem. 176, 2603 (1975).

7. Ghosh, S., Breese, K., and Bull, H. B., J. Colloid Interface Sci. 19, 457 (1964).

8. Blodgett, K. B., J. Amer. Chem. Soc. 57, 1007 (1935).

9. Bargeman, D., J. Colloid Interface Sci. 40, 344 (1972).

10. Fowkes, F. M., Ind. Eng. Chem. 56, 40 (1964).

11. Dann, J. R., J. Colloid Interface Sci. 32, 302 (1970).

12. Koenhen, D. M., and Smolders, C. A., J. Appl. Polym. Sci. 4, 1163 (1975).

13. van der Scheer, A., Feyen, J., Wubben, F. J., Krugers Dagneaux, P. G. L. C., and Smolders, C. A., J. Colloid Interface Sci., submitted for publication.

14. Bikerman, J. J., Trans. Faraday Soc. 36, 412 (1940).

15. Morrissey, B. W., and Stromberg, R. R., $J$. Colloid Interface Sci. 46, 152 (1974). 